\title{
The harmonization of animal protection during transport in the European Union - Analysis of the sanctioning systems in Italy, Romania and Spain
}

\author{
Silvia Meriggi \\ MA Animal Law and society (UAB) \\ Investigator, Animals' Angels
}

Received: May 2020

Accepted: September 2020

Recommended citation. MERIGGI, S., The harmonization of animal protection during transport in the European Union - Analysis of the sanctioning systems in Italy, Romania and Spain, dA. Derecho Animal (Forum of Animal Law Studies) 11/3 (2020). - DOI https://doi.org/10.5565/rev/da.505

\begin{abstract}
In the last sixty years, countries in Europe ${ }^{1}$ developed a common legal framework for the protection of so-called "farmed" Animals $^{2}$ : on farms, during transport and at the time of their killing. This document describes the most relevant aspects of the sanctioning systems implementing the legislation on the protection of Animals during transport ${ }^{3}$ in three countries: Italy, Spain and Romania. These nations were chosen in connection with the author's collaboration with the German non-governmental organization, Animals' Angels. The association has been investigating animal transports at the international level since 1998, with particular attention to these three countries. The article draws on findings collected from the organization's field experience as well as perspectives that have emerged over time during the analysis of the various countries. This document aims to lay out the positive and the negative points of each penalty system, as a basis for a wider analysis, and to formulate proposals for a better and uniform application of a dissuasive sanctioning system in Europe. The fact that penalties are left to the competence of the member states, which are culturally different and have different legal systems, has led to an alarmingly irregular implementation. From another perspective, with protection being put in second place, this leads to competitive distortion in the territory of the European Union. The article examines efforts made by European institutions and member states to improve the harmonisation of the application of Regulation (EC) No. $1 / 2005$. It also offers practical inputs that can be used in future negotiations of the existing laws on animal transport.
\end{abstract}

Keywords: animal transport; sanctioning system; European Union; animal protection; farmed animals; harmonization.

Resumen - La armonización de la protección animal durante el transporte en la Unión Europea - Análisis del sistema de sanciones en Italia, Rumanía y España

En los últimos sesenta años, los países europeos desarrollaron un marco legal común para la protección de los animales "de granja": en las granjas, durante el transporte y en el momento de su matanza. Este documento pretende describir los aspectos más relevantes de los sistemas de sanción que aplican la legislación sobre la protección de los animales durante el transporte en tres países: Italia, España y Rumanía. La razón por la que elegí estas naciones reside en mi colaboración con la organización no gubernamental alemana Animals' Angels. Esta asociación lleva investigando los transportes de animales desde 1998, a nivel internacional, con especial atención a estos tres países. Me gustaría utilizar algunos de los hallazgos recogidos de nuestra experiencia directa en el campo y las opiniones consolidadas durante el análisis de los distintos países. El presente documento tiene por objeto extrapolar lo positivo y lo negativo de cada sistema de sanciones, como punto de partida para un análisis más amplio, a fin de formular propuestas para una aplicación mejor y más uniforme de un sistema de sanciones disuasivas en Europa. El hecho de que las sanciones se dejen a la competencia de los Estados miembros, que son culturalmente diferentes y tienen sistemas jurídicos distintos, da lugar a una preocupante

\footnotetext{
${ }^{1}$ First as the European Economic Community, then as the European Community and finally as the European Union

2 Juridical and common language indicate with the term "farm" animals those destined for production of food and commodities in the European Union, such as cattle, sheep, pigs, horses, chickens and rabbits. The use of a capital letter for Animals is intentional, taking it as a license to give them the importance they deserve.

${ }^{3}$ Council Regulation No. 1/2005 on the protection of animals during transport and related operations, hereinafter only Reg. 1/2005
} 
falta de homogeneidad en la aplicación en la actualidad. Desde otra perspectiva, en relación a la necesidad de protección, esto lleva a una distorsión de la competencia en el territorio de la Unión Europea. Examinaré los esfuerzos realizados por las instituciones europeas y los Estados Miembros, para mejorar la armonización de la aplicación del Reglamento (CE) $\mathrm{N}^{\circ} 1 / 2005$. Además, tengo la intención de ofrecer algunas aportaciones prácticas que espero sean tomadas en serio en caso de futuras negociaciones de las actuales leyes sobre transporte de animales.

Palabras clave: transporte de animales; sistema de sanciones; Unión Europea; protección de los animales; animales de granja; armonización.

\section{A. Protection of farmed animals during transport in Europe}

In the 1960s, when the European Communities were created, live animals kept for farming purposes were already traded over long distances. Civil society was concerned about their transport conditions. The WSPA $^{4}$ lobbied for the approval of the first European law to protect farmed animals during transport, to balance economic and ethical concerns. The result was a Convention opened for signatures in $1968^{5}$. The voluntary format of the agreement soon revealed its limits. Meanwhile, the Communities developed another text, with the same aim of the Convention, which became law in 1977: Directive No. 77/489/EEC. It was the first directive for the protection of animals during transport. Subsequently this law was replaced by Directive No. 91/628/EEC, amended in $1995^{6}$. These attempts aimed at solving the same old problem that was well expressed among the whereas of Directive No. 77/489 which state ${ }^{7}$ :

"there exist between the national Laws at present in force in the field of animal transport disparities affecting the functioning of the common market",

"in order to eliminate the resultant technical barriers to trade in live animals, the laws of the member states should be harmonized...".

Nevertheless, in the early 2000s, transportation of animals increased inside, even outside the EU. Business interests seemed to prevail over ethical values expressed by the public. The EU institutions realized that member states did not enforce the directives ${ }^{8}$, and in addition, diseases were spreading ${ }^{9}$ with the traffic of animals. Consequently, the European Council invited the European Commission to make a proposal with more stringent and uniform requirements. In 2007, Council Regulation No. 1/2005 on the protection for animals during transport entered into force. As a Regulation, it has the advantage of being directly applicable in all EU Member States. This is in contrast to directives, which have to be implemented by national laws, which leads to variation among the different countries. Unfortunately, its strong binding effects did not include provisions concerning penalties, leaving autonomy to every country ${ }^{10}$ to decide which consequences derived from the violation of the Regulation ${ }^{11}$. Forty years passed (1968-2007) from the drafting of the first agreement, to limit the suffering of farmed animals during their transport in the EU, to the emergence of Regulation No. $1 / 2005$. The concerns expressed in the introduction of the Convention, in the subsequent directives and in the related reports of the Council, have remained the same and continue to be discussed in recent documents:

- increase of animal transports;

- difficulty in implementing the rules;

- uneven application of the law;

- spread of diseases due to increased transports;

- need to harmonize rules to avoid distortion of competition.

\footnotetext{
${ }^{4}$ World Society for the Protection of Animals, charity based in United Kingdom and now known as World Animal Protection

${ }^{5}$ European convention for the protection of Animals during international transport

${ }^{6}$ Directive No. 91/628/EEC was amended by Directive 95/29/EC

${ }^{7}$ Last two whereas, before article 1 of Directive No. 77/489/EEC of 18 July 1977

8 COM/2000/0809 final and Memo 01/124, Brussels, 6 April 2001 (European Commission. Webpage: europa.eu/rapid/pressrelease_MEMO-01-124_en.pdf) [last access: 09.09.2020]

${ }^{9}$ Council Resolution of 19 June 2001 on the protection of animals during transport Official Journal C 273, 28/09/2001

${ }^{10}$ Article 25 of Reg. $1 / 2005$

11 "Law without enforcement is only good advice" (Abraham Lincoln)

126 Derecho Animal. Forum of Animal Law Studies, vol. 11/3
} 
Despite many years of experience of different legal tools and of animal transports, no official document could be found recommending practical solutions, for common rules, for a uniform sanctioning system in $\mathrm{EU}^{12}$. The author therefore decided to undertake research in order to suggest concrete actions towards real harmonization.

\section{B. Rationale and method of research}

As of today, after 50 years of demands for a uniform protection of animals in Europe, and despite the proclamation that society cares about Animals ${ }^{13}$, they are not yet benefitting consistently from the basic transport conditions they deserve. The author therefore conducted research on the official web pages of the competent national authorities ${ }^{14}$ and among the findings collected by Animals' Angels ${ }^{15}$, the nongovernmental organization for which the author has worked since 2011. Animals' Angels has been investigating animal transports for 20 years, observing animals in trucks, reporting findings to, and meeting with, authorities. The sanctioning systems of Italy, Spain and Romania were analyzed for two reasons: because Animals' Angels has worked in these countries or for reasons of language comprehension. The analysis led to a compilation of a list of relevant points that characterize and influence the sanctioning systems of Regulation 1/2005: for example, the subjects of controls (inspectors) and their empowerment, strategies, legal characterization of the violations and type of penalties, training efforts. These points were used to suggest strengths of the different national sanctioning systems. It is hoped that this list of points can be useful in the near future, to design a new unique and uniform sanctioning system, directly applicable in all EU Member States.

\section{Findings C.01 Italy}

Italy was one of the founders of the European Communities and is a parliamentary republic, divided in 20 administrative regions. The Italian Constitution does not expressly protect animals ${ }^{16}$. Nevertheless, the protection of animals also has sanitary implications, of which the competence is shared between the State and the Regions. The Italian Law No. 151/2007 implements article 25 of Reg. 1/2005, providing penalties. The main authorities in charge of enforcing these laws are the Ministry of Health and the Regional Veterinary Offices, at different levels ${ }^{17}$. The Ministry coordinates the activities of the regions, defining the national policy. The regions enforce the law through their veterinary inspectors in the field. Beside the Ministry of Health, and thanks to an agreement with it ${ }^{18}$, the Ministry of the Interior supplements the veterinary inspectors with police inspectors. In practice, both, veterinary and police field officials, have the competence to check animal transports, verify if the law is complied with and in case of violations, to levy fines.

Sanctions for the violations of Reg. 1/2005 are administrative and mainly monetary fines, in the first instance, applied to all stakeholders involved in the organization of the transport (farmers, transporters, organisers). Fines vary between 1000 and 6000 euros: the most expensive concern the fitness of animals to be transported or their mistreatment but also vehicle requirements for long distances or the lack of the necessary authorizations. Sanctions are criminal when violations break penal provisions. Accessory sanctions entail the suspension or withdrawal of authorizations or the seizure of the vehicles and animals. The Italian sanctioning system has a good legal characterization of sanctions, quite faithful to the provisions of the Regulation. The best categorization of sanctions would refer to each paragraph of the original text of Reg. 1/2005, indicating

\footnotetext{
12 The only exception is the paper drafted by two NGOs, WSPA and Eyes on Animals: "Weaknesses in the animal-transport monetary sanctions - A comparative study of the effectiveness, proportion and dissuasiveness of the monetary penalties applicable to infringements of Regulation EC 1/2005 among major players of the EU". Webpage:

https://www.eyesonanimals.com/wp-content/uploads/2011/12/Downloads_WEAKNESS_IN_MONETARY_

SANCTIONS OF ANIMAL TRANSPORT(1).pdf) [last access: 09.09.2020]

13 "...the humane treatment of animals is one of the hall-marks of Western civilization...": Recommendation No. 287/1961 issued by the Consultative Assembly of the Council of Europe.

${ }^{14}$ This includes the authorities in charge of to enforcing the protection of animals during transport: ministries of health or agriculture and veterinary authorities

${ }^{15}$ Webpage: www.animals-angels.de [last access: 09.09.2020]

${ }^{16}$ Various proposals suggested to modify article 9 of the Italian Constitution, to insert, expressly, the protection of environment and of animals. The most recent proposal dates back to 2019, webpage: https://www.animal-law.it/rivista/diritto/la-tutela-degli-animalipotrebbe-entrare-nella-costituzione/ [last access: 09.09.2020]

17 "Country Profile of Italy - Organisation of official controls", DG Health and Food Safety, European Commission

18 "Protocollo d'intesa per il potenziamento dci controlli di legalità nel settore del trasporto internazionale degli animali", 3 October 2011
} 
the correspondent penalty. The amounts of Italian monetary fines are relatively high, compared to the profit of the offenders, thus sufficiently dissuasive. When animal transporters are fined in Italy for violating Reg. $1 / 2005$, and trucks are registered overseas, immediate payment must be performed ${ }^{19}$. Otherwise, the vehicle and the animals are seized. The vehicle is taken to a garage, the animals are unloaded in a place where their can be taken care of, at the expenses of the lawbreaker.

Enforcement is uneven across the regions, due to their autonomy in sanitary and veterinary matters. Enforcement is uneven also from another point of view: the number of checks carried out by police is much higher than checks carried out by veterinary officers. This was also confirmed by auditors of the EU Commission $^{20}$. The application of accessory sanctions is complicated and thus very rare ${ }^{21}$. A peculiarity of Italy is the availability $24 / 7$ of highway police to inspect animal trucks and, in some regions, of a veterinarian on shift, who can be called on by the police for joint inspections. Animals' Angels experienced this firsthand, having contacted the police in many cases, at any time of day, when serious breaches of Reg. 1/2005 were observed. The Ministries of Health and Interior have shown themselves to be open-minded, extending their collaboration to external experts ${ }^{22}$ and distributing to inspectors a practical pocket-size manual on checks on animal transports, with useful tables. This manual has helped inspectors to quickly identify violations and correspondent sanctions. Animals' Angels also organized the first series of courses to train police agents to become expert at Reg. $1 / 2005$, some of which are now training new police officers.

In general, the level of transparency concerning enforcement activities and their outcome is satisfactory in Italy. Various reports (the mandatory annual report ${ }^{23}$ and an internal one ${ }^{24}$ ), of the veterinary authorities, are published on the official website of the Ministry of Health. A national plan ${ }^{25}$ stipulates the minimum percentages of trucks to inspect yearly and sets a list of risks that should be taken into account, by each region, to schedule checks. Unfortunately, not all of them drew up a regional plan, based on the specific risks, linked to the characteristics of their territory (e.g. intense presence of certain types of farms and slaughterhouses; presence of control posts; if they are bordering regions or transit regions affected by specific movements).

\section{C.02 Romania}

Romania is a semi-presidential republic, which joined the European Union in 2007. It is divided into 41 administrative counties. The central authority of ANSVSA $^{26}$ is subordinated to the government and coordinated by the Prime Minister, having competences in veterinary and food safety, including animal welfare. Despite the legislative power belonging to the parliament, the government has the power of initiative and also the power to adopt decisions for the execution of laws. In fact, ANSVSA adopted Decision No. 984/2005 ${ }^{27}$ to implement article 25 of Reg. 1/2005. The only authorities in charge of enforcing the Regulation on the spot are official veterinarians entitled ${ }^{28}$ to carry out inspections and levy fines. They are employed by the county veterinary offices. Unfortunately, human resources are very limited and burdened with other duties ${ }^{29}$.

Agreements with police inspectorates have been concluded so that in theory police officers will help veterinarians, to stop trucks during road-checks and to keep order and security. Nevertheless, Romanian police officers have a limited competence for some documental checks ${ }^{30}$. In one instance, Animals' Angels informed the border police of south Romania of trucks appearing to be in breach of the Regulation. The organization

\footnotetext{
${ }^{19}$ The Italian national law, D. Lgs. No. 151/2007, article 12, refers to the Italian Road Traffic Code, article 207

${ }^{20}$ EU Commission audit report DG(SANCO) 2011-6048

${ }^{21}$ This can happen if the offender pays the fine, or in case of appeal, when the courts release the final decision (res judicata).

${ }^{22}$ Annual report on the protection of animals during transport of Italy, 2012, page 38: "Regular training courses continue to be organized with the active participation of experts from the Ministry veterinary services, the Regions and the local health authorities, and experts from the animal protection organizations of Lav and Animals' Angels"

${ }^{23}$ Mandatory on the base of Regulation (EC) No 1/2005, art. 27

${ }^{24} \mathrm{http}: / /$ www.salute.gov.it/imgs/C_17_pubblicazioni_2865_allegato.pdf [last access: 09.09.2020]

${ }^{25}$ Published in the official website of the Ministry of Health, webpage:

http://www.salute.gov.it/pianoNazionaleIntegrato2015/homePianoNazionaleIntegrato2015.jsp [last access: 09.09.2020] See also: http://www.salute.gov.it/relazioneAnnuale2018/homeRA2018.jsp [last access: 09.09.2020]

${ }^{26}$ Autoritaea Nationala Sanitara Veterinara si pentru Siguranta Alimentelor (the national sanitary, veterinary and food safety authority of Romania)

${ }^{27}$ Decision No. 984/2005, concerning the violations of the sanitary-veterinary and food safety laws in Romania, had been amended in 2008 by Government Decision No. 30, to introduce the sanctions connected to the violation of Reg. 1/2005

28 See Ordinance No. 2/2001, article 15 and Ordinance No. 42/2004, Chapter III

29 Example: letter of DSVSA Suceava, protocol No 8254/19.05.2016 to ANSVSA. See webpages: https://www.digi24.ro/stiri/actualitate/social/animalele-chinuite-neprotejate-de-lege-606900, https://www.ziaruldeiasi.ro/stiri/stitica-exista-politia-animalelor-in-ia-i-are-un-singur-angajat--140341.html [last access: 09.09.2020], as more examples.

30 Decision No. 984/2005, article 11(4): "Contravenţiile prevăzute la art. 3 lit. a) pct. 2, lit. b) pct. 1, 2 şi 9 şi la lit. c) pct. 3 se pot constata şi sancţiona şi de către poliţişti”
}

128 Derecho Animal. Forum of Animal Law Studies, vol. 11/3 
asked the police to stop the trucks and call the veterinarians for a joint check, but they denied their competence to do so, apparently not aware of any agreement. Police officers are neither trained neither empowered to enforce Reg. 1/2005 in Romania.

Sanctions are basically pecuniary contraventions. Offenders can be individuals or legal persons. Fines are much heavier when they are committed by companies, varying approximately between 6000 and 30000 $\mathrm{lei}^{31}$. The most expensive are levied in case of violations concerning unfit animals (injured/ill animals), emergency plans, navigation systems, journey time and mandatory intervals, transport practices, requirements of vehicles and accompanying documents. The amount of the monetary fines is heavy in general, especial for companies, thus dissuasive. On the other hand, according to the official documents ${ }^{32}$, the number of checks and sanctions applied is scarce, compared to Italy, for example. This manifests itself in an imbalance that leads to distortion of competition among transporters in EU Member States. Furthermore, according to the research carried out for this article, there is no provision in the Romanian road code, contrarily to the Italian system, in which foreign transporters must pay fines immediately on the spot, when infringements of Reg. $1 / 2005$ are detected. Because of the lack of this provision, foreign transporters may decide not to pay the fines, counting of the fact that execution procedures outside Romania are complicated. This causes an unfair treatment between Romanian and foreign transporters. Despite the quite good legal tool to enforce Reg. 1/2005 in Romania, there seems to be a lack of specific attention to the welfare of the animals, in favor to documental formalities and food safety issues ${ }^{33}$. This aspect stands out in the annual reports on the protection of animals during transport. Animals' Angels complained about it, reporting unlawful transport conditions of animals at local markets ${ }^{34}$ but also during the intense export of sheep ${ }^{35}$ to other EU countries. This limitation was also noted by the European Commission ${ }^{36}$ and recognized by the Romanian authorities themselves.

It proved extremely difficult to find documents reporting the outcome of the inspections on official websites $^{37}$. The official website of ANSVSA published the new MANCP of Romania ${ }^{38}$. Like the previous versions of it, it contains little information about checks on animal welfare during transport and it still lacks essential aspects such as risk analysis and strategies ${ }^{39}$ based on previous outcomes and on territorial peculiarities of Romania. For example, Romania is a transit country, has intense movements to export lambs in certain seasons and temperatures that reach extreme values in summer and winter. Neither the most relevant types of transports to check or the period of the year are mentioned in any paragraph of the planning. The mandatory annual reports contain very poor analysis and plans of initiatives to improve enforcement.

\section{C.03 Spain}

Spain is a constitutional monarchy organised in 17 autonomous communities with their own government. The central Ministry of Agriculture coordinates the autonomous ministries on animal welfare policies. Each community is responsible for implementing animal welfare legislation through its veterinary units. Spanish veterinary officers checking animal transports are not empowered to levy fines on the spot, if they ascertain violations of Reg. 1/2005. In some Spanish autonomous communities, police forces can also carry out checks on animal transports, but they are not empowered to levy sanctions either. Police must call a veterinary officer who, in any case, does not have the power to levy sanctions on the spot. The central veterinary offices oversee, analyzing the findings of the officers involved in the checks and, if necessary, raising the corresponding penalties. The communities may also issue their own legislation. Consequently, many laws overlap, and their hierarchy is not very clear at first glance.

\footnotetext{
${ }^{31}$ Romanian currency equals to 0.21 euro, according to google extracted on 18.01.2019 at 13:34 UTC

${ }^{32}$ Annual reports on the protection of animals during transport of Romania, according to art. 27 of Reg. 1/2005

${ }^{33}$ Example: Letters of veterinary directorate (DSVSA) of county Giurgiu, protocols No. 1360 of 20.01.2016 and No. 4200/11.03.2016

${ }^{34}$ Animals' Angels reports: "Formal complaint by Animals' Angels to the European Commission, concerning systematic failure by Romanian authorities to secure compliance with Council Regulation EC No. 1/2005 for the protection of animals during transport and related operations in animal markets in Romania”, November 2014 and Letter of Animals' Angels to the EU Commission concerning animal transport to Romanian traditional markets - update of Complaint CHAP(2014)03700, 15.02.2016

${ }^{35}$ Animals' Angels reports: "Easter slaughter in Romania - An investigation of Animals' Angels 7-14 April 2017" and Animals' Angels report: "Transport of sheep for slaughter, from Romania to Greece, 19.-20.12.2017" and "Transport of sheep for slaughter, from Romania to Greece, 17. - 18.12.2017" and "Transport of sheep for slaughter, from Romania to Bulgaria 22.12.2017 " and" Transport of lambs for slaughter from Romania to Greece, 01./03.04.2018"

36 Letter of the EU Commission, Ref. Ares (2016)7135068 - 22/12/2016, Audit Report of the EU Commission, Ref. Ares(2013)1846550 - 07/06/2013 and Fact Finding Mission of EU Commission in Romania from 26 to 30 October 2015 and Letter Ref. Ares(2016)7135068 - 22/12/2016 and Audit Report of the EU Commission, Ref. Ares(2018)2908268 - 04/06/2018

${ }^{37}$ Webpage of Ansvsa: www.ansvsa.org [last access: 09.09.2020]

38 See webpage: http://www.ansvsa.ro/download/pncui/pncui-plan_anual/2017-2019-Planul-National-Multianual-Unic-De-ControlIntegrat-Pentru-Romania.pdf [last access: 09.09.2020]

${ }^{39}$ According to articles 110(b) and 111(2) of Regulation 2017/625/EU on official controls on animal welfare
} 
Before Reg. 1/2005 came into force, and at the time of the previous European directives on the protection of animals during transport, nearly all Autonomous Communities set their rules on the matter, between 1990 and 2003. These texts have not been apparently updated, after the Regulation. Instead, at the national level, Law n. 32/2007 "para el cuidado de los animales, en su explotación, transporte, experimentación y sacrificio 40 " provided sanctions for the violation of the Regulation and of other laws concerning animal protection (on farms and during slaughter, for example). A very general provision includes violations concerning animal welfare during transport, referring very generally to "failure to comply with the obligations required by animal protection standards for the care and handling of animals". It calls for minor, serious or most serious sanctions, depending on, respectively, if there is no permanent damage caused to the Animals, if there are or if there is the intention to torture or to cause death to them. Violations concerning animal transport are generally minor, therefore accessory sanctions, which apply only to serious offences, apparently never apply for most animal transport breaches. In the case of minor infringements, like those violating Reg. 1/2005, a fine not exceeding 600 euros or a warning shall be imposed. In the case of the laws of the autonomous communities, most of the violations concerning animal transports fell under minor offences and only in case of mistreatment, injuries and death they are serious. Generally, the amounts of minor offences are a maximum of 150.25 or 300.51 euros. Sanctions in Spain are not at all dissuasive ${ }^{41}$, something that was also confirmed by the auditors of the European Commission ${ }^{42}$.

As one reads the Multi Annual National Control Plan of Spain, called "Official control of the food chain" of 2016-2020, the impression is that the Spanish sanctioning system is very fragmentary and uneven. The MANCP puts little effort into trying to keep track of all the challenging differences. According to this document, Spain does not even have a general manual, valid for all field inspectors, providing written procedures, concerning checks on animal transports for veterinarians. Instead, a guide for the police forces was published in 2017. As in Romania, annual reports lack a real analysis and action plan. Those accompanying Spanish reports are meagre and superficial.

\section{Outcome of the comparison}

The sanctioning systems of Spain, Italy and Romania are very different from each other, beginning with the legal definition of the offences, through to the different figures in charge of enforcement and empowered to levy fines.

All three countries provide mainly monetary sanctions, in case of violations of Reg. $1 / 2005$, of very different amounts. To give some examples:

\begin{tabular}{|l|l|l|l|}
\hline VIOLATION & PENALTY IN ITALY & $\begin{array}{l}\text { PENALTY IN } \\
\text { ROMANIA }\end{array}$ & PENALTY IN SPAIN \\
\hline $\begin{array}{l}\text { Too many animals } \\
\text { loaded }\end{array}$ & 1000 euro & 1292.52 euro $(6000$ lei) & $\begin{array}{l}\text { Up to 600 euro or a } \\
\text { warning }\end{array}$ \\
\hline $\begin{array}{l}\text { Water system not } \\
\text { functioning }\end{array}$ & 2000 euro & $\begin{array}{l}\text { Up to 600 euro or a } \\
\text { warning }\end{array}$ \\
\hline Unfit animals & 2000 & 38777.57 euro (18000 lei) & $\begin{array}{l}\text { Up to } 600 \text { euro or a } \\
\text { warning }\end{array}$ \\
\hline
\end{tabular}

The national control plans of all the three countries do not fulfill the legal provisions regarding risk analysis and risk-based checks. The annual reports reflect such a lack, in particular because they are accompanied by very superficial analysis and action plans. The Italian MANCP and accompanying analysis get closer to the legal requirements ${ }^{43}$, than the Romanian and Spanish. The multi annual planning mentions, at least, some risks for the Regions to keep into consideration, when drafting their official controls on animal transport. The analysis of the annual reports in Italy are definitely longer and apparently more structured than the Romanian and Spanish ones. Nevertheless, at a deeper look, they also do not contain a real statistical study and interpretation of the collected data.

\footnotetext{
${ }^{40}$ i.e., in English: for the protection of animals on the farm, during transport, vivisection and slaughter

41 "legal departments of the ACs can impose a maximum fine of $€ 600$ as this offence is graded in the annex to the Law on Sanctions as a light offence. In practice sanctions for farmers or transporters were usually $€ 150-200$ after appeal which are not proving to be effective at addressing this issue", pages 13-14 of the audit report DG(SANCO) 2014-7079.

${ }^{42}$ Recommendation 9 of audit report DG(SANCO) 2008-8047

${ }^{43}$ See footnote 39

130 Derecho Animal. Forum of Animal Law Studies, vol. 11/3
} 
The following table was compiled after analysing strengths and weaknesses of the three compared countries. It summarizes key factors influencing, in general, an effective sanctioning system for the violation of Reg. 1/2005:

\begin{tabular}{|l|l|}
\hline \multirow{2}{*}{ STRATEGY } & Thorough ${ }^{44}$ national and regional plans \\
\cline { 2 - 2 } & Annual reports with professional analysis and action plan \\
\hline \multirow{4}{*}{ TRAINING } & Pocket-size manual for inspectors \\
\cline { 2 - 2 } & Standardized training \\
\cline { 2 - 2 } EMPOWERMENT & Training provided by an expert group of inspectors \\
\hline COORDINATION & $\begin{array}{l}\text { Agreements between police and veterinarians/respective ministries } \\
\text { Contact persons for information exchange }\end{array}$ \\
\hline EFFECTIVENESS & High monetary sanctions \\
\cline { 2 - 2 } & $\begin{array}{l}\text { Three levels of intensity: minor, serious, most serious } \\
\text { infringements/correspondent sanctions }\end{array}$ \\
\cline { 2 - 2 } & $\begin{array}{l}\text { Clear and thorough legal categorization of offences, based on Reg. 1/2005 } \\
\text { definitions }\end{array}$ \\
\cline { 2 - 2 } & Easy procedure to impose accessory sanctions \\
\cline { 2 - 2 } & European database to track repeat offences \\
\cline { 2 - 2 } & On-the-spot payment and seizure of trucks and animals for foreign offenders \\
\hline TRANSPARENCY & $\begin{array}{l}\text { National and regional plans, official reports and contact for animal transport } \\
\text { checks published on government websites }\end{array}$ \\
\hline
\end{tabular}

\section{E. Theory for the harmonization of the sanctioning system of Reg. 1/2005}

How can the sanctions for the violation of Regulation (EC) No. 1/2005 be harmonized in all Member States of the EU? How can practices and enforcement be improved? The production of the Transport Guidelines in 2017 took three years, from 2015 to 2018, and required an investment of 990.000 euros of EU funds, but it is soft law. Drivers, who were among the final recipients, are not familiar with them, after 3 years, and veterinary inspectors claim that they do not have legal force. Should every national sanctioning system be modified? This would be too complicated and time-consuming and would again be left to the discretion of each member state, as was the case with article 25 of the Regulation.

It took 40 years to conclude that a common legal framework was the only solution to harmonize the protection of animals during transport. It should now be clear that a regulation directly applicable to all EU Member States is the only solution to harmonise the correspondent sanctions. To the question of whether such harmonisation is possible, the answer is yes. European laws must be applied to members and citizens of the European Union equally, as per the Treaty on the Functioning of the European Union, article 8. This does not happen for Reg. 1/2005, as animal transporters meet with different legal consequences, depending on the country in which they are checked by authorities. In the same way, farmed animals, which are transported for commercial reasons, are treated differently, depending on the country in which they are inspected. Articles $114,115,116,117$ of the TFEU point to the need to harmonise regulations and administrative actions in the EU Member States, when they concern the functioning of the internal market and when competition is distorted. Furthermore, the Council and European Parliament shall set out appropriate measures to implement the common transport policy (articles 90, 91 of TFEU).

\section{F. Proposals}

The European Union must issue a regulation containing the sanctions for the violation of Reg. 1/2005, on the basis of the above mentioned articles of the TFEU because:

- at present, different sanctions apply to the offenders of the same provision, when they are fined in different member states;

- for this reason (and others), the internal market of live transport is distorted ${ }^{45}$.

\footnotetext{
${ }^{44}$ Risk assessment in animal welfare - Especially referring to animal transport M. Marahrens,*, N. Kleinschmidt, A. Di Nardo, A. Velarde, C. Fuentes, A. Truar, J.L. Otero, E. Di Fede, P. Dalla Villa

${ }^{45}$ The White Paper of 2010, of the European Commission, mentions the same principles to harmonise penalties in the context of
} 
The European Union has already issued directives and regulations containing sanctions, or indications for harmonized sanctions, for various important matters, which needed to be harmonized in EU (e.g. data protection, market abuse, professional transport), to align the differing competitive conditions. Particularly interesting is the case of Commission Regulation (EU) No. 2016/403 ${ }^{46}$. This law set up a list of categories, types and degrees of seriousness of serious infringements of Union rules, which may lead to the loss of good repute of the road transporter undertaking or the transport manager. According to the Commission, this was a step forward ensuring fair competition and harmonised enforcement. In 2013 a law firm published a comparative study, for the European Commission ${ }^{47}$, that highlighted relevant disparities, among the different national laws concerning road transport. The regulation of 2016 has been an attempt to harmonise transport sanctions in the EU.

This paper proposes:

1) to include animal transport in the EU transport policy on commercial road transport and its harmonization process;

2) that the European Commission, DG Sante, commissions a comparative study from a law firm, to analyse and compare each national sanctioning system for animal transport, in the $27 \mathrm{EU}$ Member States ${ }^{48}$, including legal categorizations of violations, sanctions, empowerment and concluding with a proposal for their harmonization;

3) to directly amend Regulation $1 / 2005$ or to issue a new regulation, providing sanctions of different levels of intensity, for minor, serious and most serious infringements of Reg. 1/2005. The Regulation must provide minimum and maximum limits of the amount of the monetary penalties. It shall also indicate supervising authorities, including police forces and not only veterinary officers. It shall grant investigative and corrective powers to all field inspectors. It shall supply tables listing offences and sanctions, in order to simplify the application of the law. It shall also provide templates for the compilation of professional control plans and of analysis and action plans accompanying annual reports.

\section{G. Conclusion}

Regulation No. 1/2005 on the protection of Animals during transport and related operations is not easy to interpret, thus not easy to implement, despite the EU policy to keep the law simple ${ }^{49}$. This, in addition to the differences among the Member States of the European Union, impedes the effective enforcement of the protection of farmed Animals. That the Regulation needs to be amended to improve its applicability was argued extensively by the organisation Animals' Angels, in its many complaints as well as its document, "The Myth of Enforcement" ${ }^{\text {"50 }}$. Despite the awareness of the member states, and of the European Commission too ${ }^{51}$,

commercial road transport (pages 13, 22, 25).

46 Commission Regulation (EU) 2016/403 of 18 March 2016 supplementing Regulation (EC) No $1071 / 2009$ of the European Parliament and of the Council with regard to the classification of serious infringements of the Union rules, which may lead to the loss of good repute by the road transport operator

47 "Study on sanctions in the field of commercial road transport" - Contract no 2011/MOVE/D3/ETU/514-2011/SI2.612723 February 2013, submitted by Studio Legale Grimaldi to the European Commission

${ }^{48}$ Report from the Commission to the European Parliament and the Council on the impact of Council Regulation (EC) No 1/2005 on the protection of animals during transport: "such a comparison has not been carried out by the Commission. However, estimation based on the information available shows significant variations when it comes to the level of penalties for infringements of the Regulation across the European Union", page 12

49 See ,Interinstitutional agreement between the European Parliament, the council of the European Union and the European Commission on better Law-making interinstitutional agreement of 13 April 2016 on Better Law-Making and REFIT - making EU law simpler and less costly. "The European Commission's regulatory fitness and performance (REFIT) programme aims to ensure that EU legislation delivers results for citizens and businesses effectively, efficiently and at minimum cost. REFIT aims to keep EU law simple, remove unnecessary burdens and adapt existing legislation without compromising on policy objectives". Webpage https://ec.europa.eu/info/law/law-making-process/evaluating-and-improving-existing-laws/refit-making-eu-law-simpler-and-lesscostly_en [last access: 09.09.2020]

${ }^{50}$ See webpage:

https://www.animals-

angels.de/fileadmin/user_upload/03_Publikationen/Dokumentationen/Animals_Angels_Myth_of_Enforcement.pdf [last access: 09.09.2020]

51 As an example, see "Report from the commission to the European Parliament and the Council on the impact of Council Regulation (EC) No $1 / 2005$ on the protection of animals during transport" of 2011 of the European Commission, page 15 “...ambiguities and inefficiencies in the current animal welfare legislation..."

132 Derecho Animal. Forum of Animal Law Studies, vol. 11/3 
of the limits of this Regulation, the policy of the latter has been, so far, since Reg. 1/2005, to produce soft law and improve enforcement. It is clear, however, that non-binding rules can't change binding rules. The European Commission carried out a series of study visits to exchange best practices among the Member States, concerning the enforcement of the protection of animal transport in 2013-2014 ${ }^{52}$, as scheduled in the impact report ${ }^{53}$. Nevertheless, we are still far from a harmonised application of the regulation and of the "better practices" exchanged in those visits ${ }^{54}$. The European Commission recognized the need for a comparative study ${ }^{55}$, concerning the penalty system of Reg. 1/2005 of all Member States, but it has not yet been commissioned. Thirteen years have passed, since the Regulation has come into force, authorities have become aware of its limits and efforts to improve enforcement have been made. Over the last sixty years, attempts have been made to protect farmed Animals in Europe during transport and to formulate a harmonized approach. Now it is time to act coherently. Regulation No. 1/2005 must be amended and must carry uniform penalties or criteria for penalties that are implemented in all Member States. Even when the basic protection provided by the Regulation is finally enforced, European farmed Animals will not be protected according to the real meaning of the word "protection". Farmed Animals will be truly protected when people will stop farming them and they will not be traded like goods, transported all over the world to be fattened or killed, deprived of their own personality and dignity and right to exist. Nevertheless, society has demanded that these Animals be protected somehow, meaning that, at the very least, they be spared unnecessary suffering. Legal protection is the minimum that European and national institutions should provide, using all their powers to fulfill the request of their citizens ${ }^{56}$ and to fulfill the content of their own laws. While Animals continue to travel crammed in trucks and without space to lie down or reach drinking devices, and while authorities consider this to be in compliance with the law, there will be protection only of the economic interests of a very small part of society, which makes profits out of the loopholes in the law. This is simply unfair.

\footnotetext{
52 "Study visits to improve Member State controls on animal welfare during transport" of the European Commission, 2015

${ }^{53}$ Report from the commission to the European Parliament and the Council on the impact of Council Regulation (EC) No 1/2005 on the protection of animals during transport" 2011 of the European Commission, page 14

${ }^{54}$ One of the identified best practices was the possibility to impose sanctions on the spot to foreign transporters, in case of violations of Reg. 1/2005

${ }^{55}$ Report from the commission to the European Parliament and the Council on the impact of Council Regulation (EC) No 1/2005 on the protection of animals during transport" 2011 of the European Commission, page 12

${ }^{56}$ In 2011, Animals' Angels launched the 8hours petition, asking that animals are not transported for more than eight hours in total. 1,103,248 signatures were handed in to the European Commissioner for Health in June 2012. Over 140 MEPs expressed support for the campaign. The European Parliament adopted a Written Declaration No 49/2011 in March 2012, demanding the 8-hour limit.
} 